Portland State University

PDXScholar

7-10-1986

\title{
After the Sixties: Anthropology in Sixth Grade Social Studies Textbooks
}

Christine Skei Rossi

Portland State University

Follow this and additional works at: https://pdxscholar.library.pdx.edu/open_access_etds

Digitart of the Anthropology Commons, and the Education Commons comenens know how access to this document benefits you. Network

Logo

Recommended Citation

Rossi, Christine Skei, "After the Sixties: Anthropology in Sixth Grade Social Studies Textbooks" (1986). Dissertations and Theses. Paper 3691.

https://doi.org/10.15760/etd.5575

This Thesis is brought to you for free and open access. It has been accepted for inclusion in Dissertations and Theses by an authorized administrator of PDXScholar. Please contact us if we can make this document more accessible: pdxscholar@pdx.edu. 
AN ABSTRACT OF THE THESIS OF Christine skei Rossi for the Master of Arts in Anthropology presented July 10, 1986.

Title: After the Sixties: Anthropology in Sixth Grade Social studies Textbooks.

APPROVED BY MEMBERS OF THE THESIS COMMITTEE:

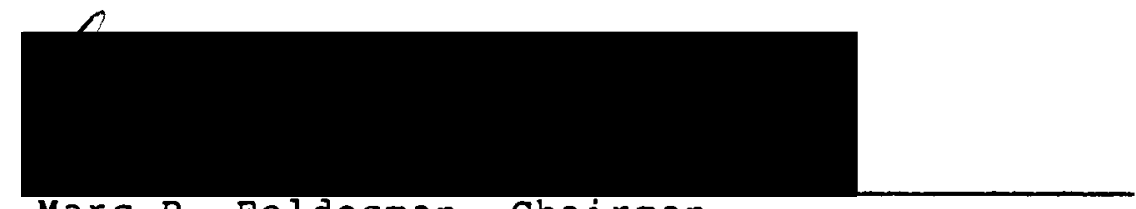

Marc R. Feldesman, Chairman

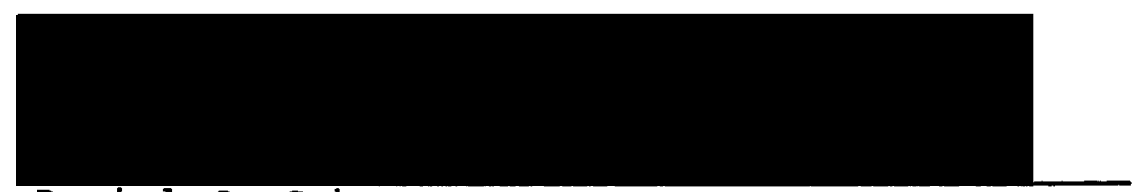

Daniel J. Scheans

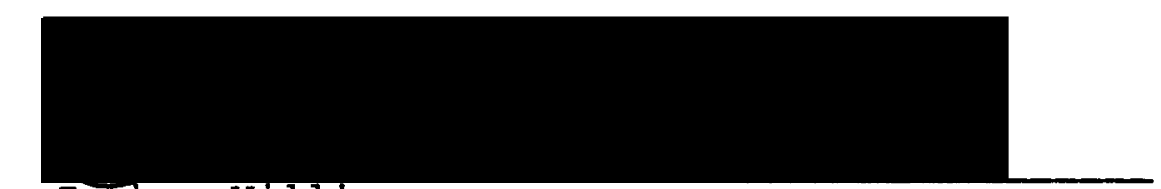

Forbes Williams

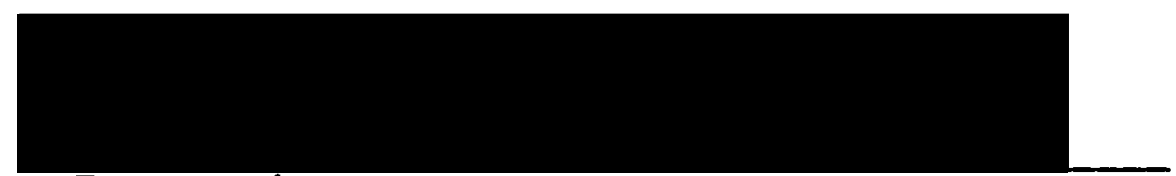

Tom E. Thomas

During the 1960s, anthropology was an important part of the social studies curriculum. This study explores the question of whether twenty years later, anthropology is still an important part of primary and secondary school curricula and textbooks. To answer that question, the author used content analysis to analyze 13 sixth grade social 
studies textbooks for their anthropological content. Results of the research indicate that there is very little anthropology in the texts, the same topics and concepts are covered in most of them, and that most of the anthropological material is narrative or descriptive in form rather than theoretical. The exclusion of anthropology from the textbooks would seem to be tied in with the process of textbook production, publishing, and adoption. If anthropologists wish to see more anthropology in textbooks, then they will have to involve themselves in the textbook process. 


\title{
AFTER THE SIXTIES: ANTHROPOLOGY IN SIXTH GRADE SOCIAL STUDIES TEXTBOOKS
}

by

\section{CHRISTINE SKEI ROSSI}

A thesis submitted in partial fulfillment of the requirements for the degree of

\author{
MASTER OF ARTS \\ in \\ ANTHROPOLOGY
}

Portland state University 
TO THE OFFICE OF GRADUATE STUDIES AND RESEARCH:

The members of the Committee approve the thesis of

Christine Skei Rossi presented July 10, 1986.

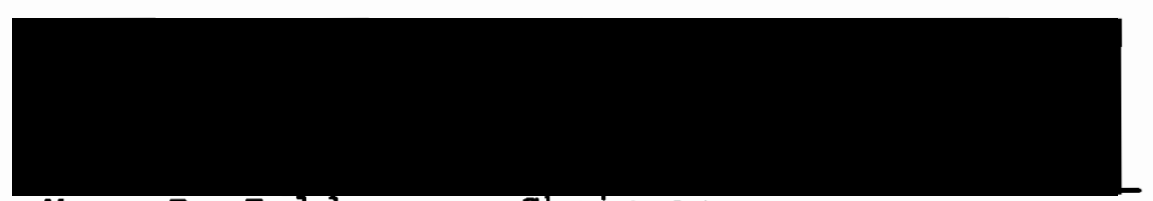

Marc R. Feldesman, Chairman

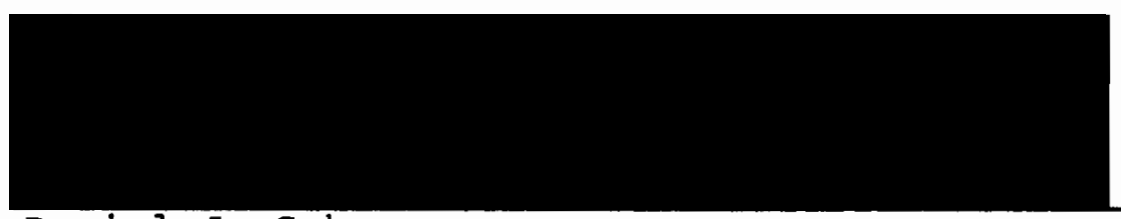

Daniel J. Scheans
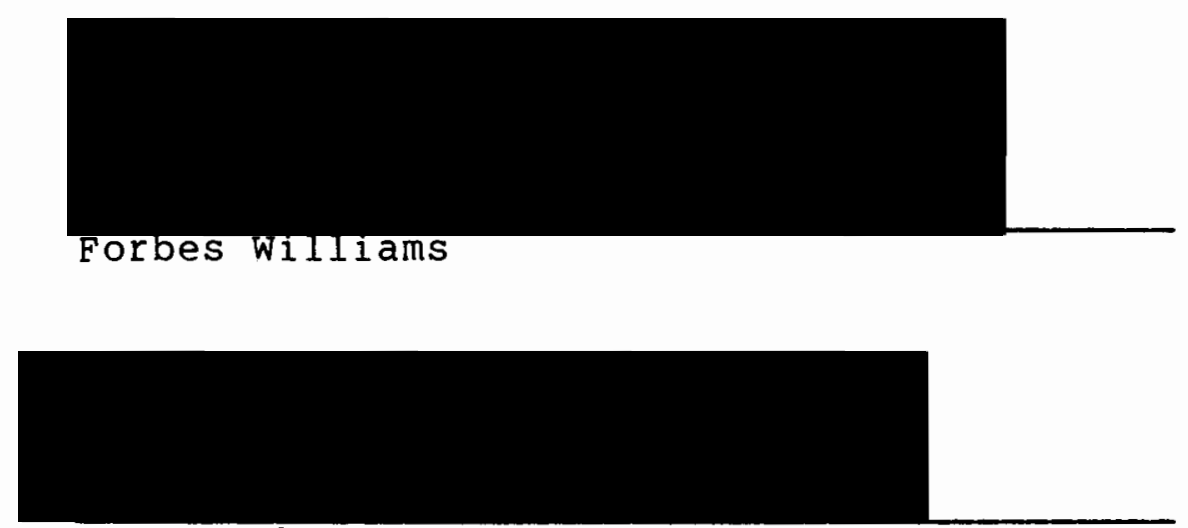

Tom E. Thomas

APPROVED :

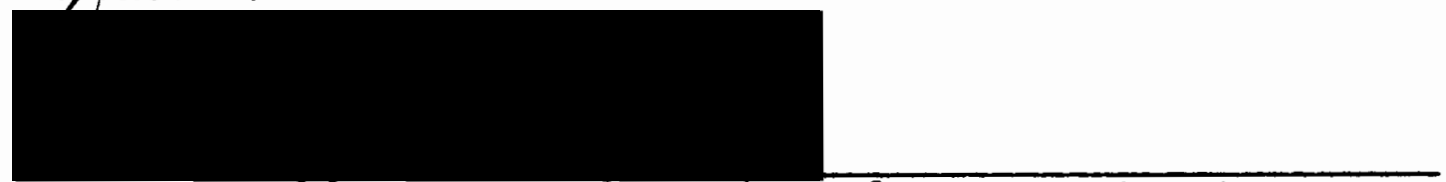

Marc R. Feldesman, Head, Anthropology Department

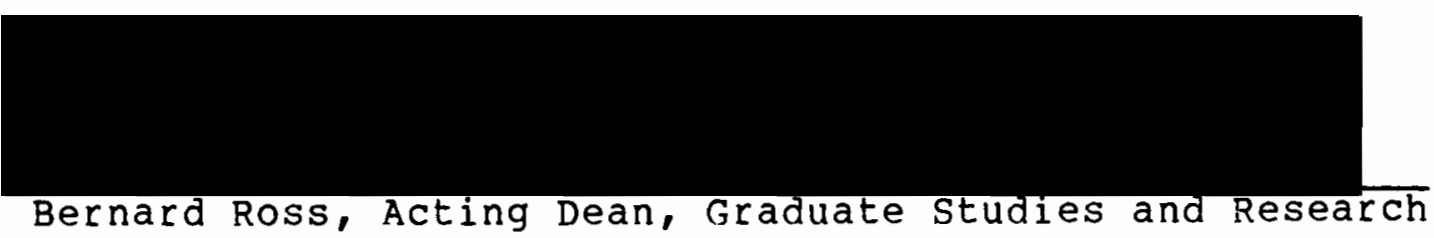




\section{ACKNOWLEDGMENTS}

Many, many people have been helpful and supportive in the preparation of this thesis. To Marc Feldesman I will be forever indebted for suggesting the thesis topic, for giving me unending guidance, for putting up with my occasional despair, and for providing an academic role model. My husband Bill paid the bills, prodded me when I needed prodding, and always listened. My children, Lise and Alex, seemed to understand what I was going through and were consistently thoughtful of my needs.

The members of my thesis committee, Dan scheans, Forbes Williams, and Tom Thomas, provided excellent advice and direction. Mary Dozark listened, and told me she had seen it a million times before. The members of the Anthropology Department, Ken Ames, John Atherton, Ann Bennett, Jack Fried, Tom Newman, Joe Pierce, and Wayne suttles all helped lay the intellectual foundation for the thesis.

To all of these people, I express my utmost thanks. 
TABLE OF CONTENTS

PAGE

ACKNOWLEDGMENTS .......................... i i

LIST OF TABLES ............................ vi

LIST OF FIGURES.......................... vii

CHAPTER

I INTRODUCTION ..................... 1

Historical Background................ 1

Statement of the Problem............. 4

Rationale for the Inclusion

of Anthropology in the social

studies curriculum.............. 5

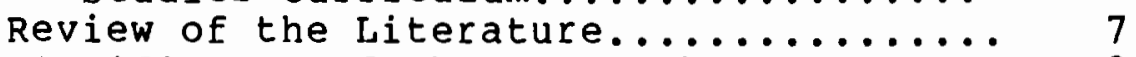

Significance of the Research.......... 9

I I METHODOLOGY...................... 11

Textbook Analysis Methods............ 11

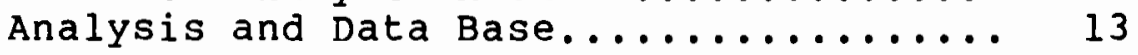

II $\quad$ RESULTS.............................. 19

Anthropological Topics and

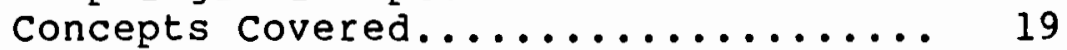

Quality of the Anthropology........... 21

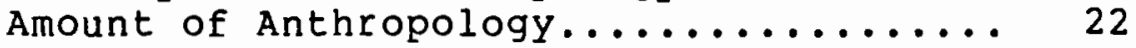

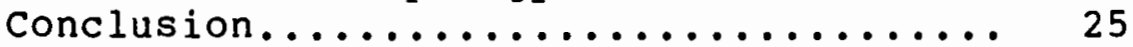

IV $\quad$ DISCUSSION....................... 26

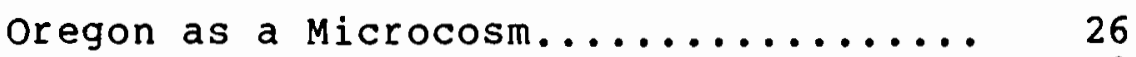

Textbook Adoption procedures.......... 28

The Exclusion of Anthropology......... 30

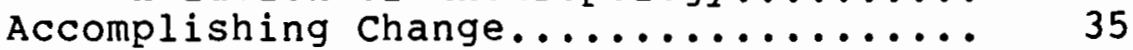

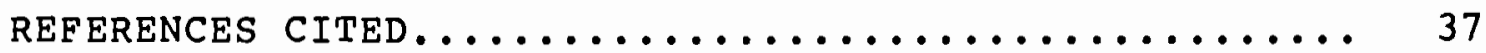

APPENDIX A.................................... 43 
PAGE

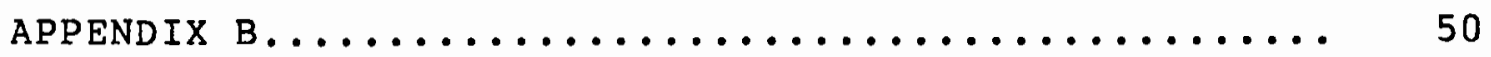

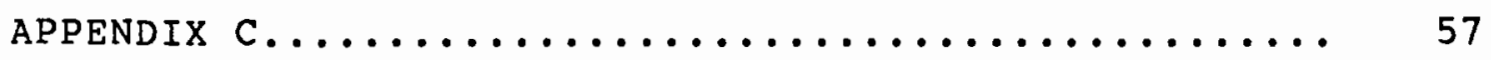

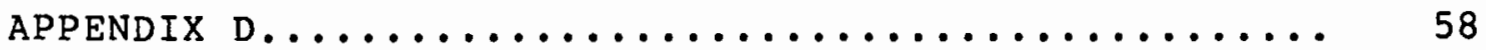




\section{LIST OF TABLES}

TABLE

PAGE

I Topics............................. 14

I Topics and Concepts Covered............. 20

II Amount of Anthropology............... 23

IV Selected characteristics of the United states, oregon, and other states and

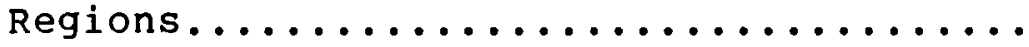




\section{LIST OF FIGURES}

F IGURE

PAGE

1 .

The Cronbach Model. 


\section{INTRODUCTION}

This thesis will explore the question of whether or not a certain group of social studies textbooks contains anthropological topics and concepts. After giving a brief history of how anthropology was an important part of the social studies curriculum in the 1960s, I will discuss the rationale for the inclusion of anthropology in the social studies curriculum.

Further on, I discuss textbook analysis methods and my own method of analysis. The results of my research include information on what anthropological topics and concepts were covered in the texts, what the quality of the anthropology was, and the amount of anthropology I found in the texts. In the Discussion section of the thesis I consider how textbook adoption procedures affect the content of textbooks and processes that work against the inclusion of anthropology in texts. I conclude the thesis with suggestions on how anthropologists might work to accomplish change in social studies textbooks.

\section{Historical Background}

The 1960s, a time of social and political ferment in the United States, was also a time when anthropology was an important part of the social studies. Anthropology's role 
in the social studies curriculum had been in large part brought about by the New social studies (Barr 1977), a movement greatly influenced by Jerome Bruner's book The Process of Education (1960).

One of Bruner's most influential beliefs was that "...any subject can be taught effectively in some intellectually honest form to any child at any stage of development" (Bruner 1960:11). The implication of this statement was obvious to historians and social scientists: the concepts, generalizations, methods, and models of their disciplines could be taught to school age children (Barr, 1977). Dynneson (1975:29) gives this background of the shift to the New Social studies and the increased focus on anthropology:

If one were to cite a single event that gave the strongest impetus to this shift [to the philosophy of the New Social studies], it would be the Russian launching of sputnik in 1957. This stimulated a pervasive fear in the United states that the Soviets llre pulling ahead of this country scientifically and technologically. Numerous institutions came under severe criticism for their failures to maintain or help maintain American supremacy; and, of course, educational institutions were among the major targets of critics. In response to the hue and cry, Congress passed legislation designed to stimulate improvement in the quality of educational programs in the sciences. The first areas of the curriculum to receive attention under these new federal programs were the natural sciences and mathematics. Soon after, the social sciences, too, came to be included in the federal effort to stimulate educational improvement. Anthropology was included among these and this marked the beginning of a serious, nationally based effort to incorporate anthropology into the school curriculum. 
Funds were available for curriculum development from the National Science Foundation, Project Social studies of the Office of Education and various private sources. Eventually, more than fifty social studies curriculum development projects were funded, the vast majority being "attempts to teach history and the social sciences as ends in themselves" (Barr, Barth, and Shermis 1977:43).

Only three of the projects were composed primarily of anthropological material. The Anthropology Curriculum Project, located at the University of Georgia, produced an anthropological course of study for grades $k-7$. The Education Development Center, developed Man: A Course of Study (MACOS), which became quite well-known and controversial. The Anthropology Curriculum study Project, based at the University of Chicago, sponsored by the American Anthropological Association, and funded by the National Science Foundation, developed a high school anthropology course, Patterns of Human History, and two junior high school units, all subsequently published by Macmillan (Dynneson 1975).

Other projects incorporated quite a bit of anthropology, but were not exclusively anthropological. These included The University of Minnesota Project Social Studies, The High School Geography Project, published by The Macmillan Company, and The Taba Program in Social Science, published by Addison Wesley. By 1972 development of these 
curriculum projects was complete and most of the materials had been acquired by commercial publishers (Dynneson 1975).

\section{Statement of the Problem}

When I first began to study the connections between anthropology and social studies, I wondered what had happened to anthropology after the New Social studies. Brought into the forefront of social studies during the 1960s, had anthropology now receded into the background once again, or had it become a part of the primary and secondary school curricula and textbooks?

To answer that question, I decided to look at social studies textbooks to see if they contained any anthropology. According to Keith (1981), textbooks are, along with the teacher, the student's major source of knowledge and information. Approximately 90 percent of classroom time involves curriculum materials, and about two-thirds of that time is spent with printed materials, mostly textbooks (EPIE, 1977).

The texts I decided to analyze were the social studies textbooks adopted in 1979 (see Appendix C) by the oregon state Board of Education for use in sixth grade classrooms. I chose sixth grade textbooks for two reasons. The first was that the oregon state Textbook Commission's textbook category for grades $4-6$ is "Living in Regions and Nations" and "Comparative cultures - Past and Present" (Oregon 
State Textbook Commission, 1978). The second was that I felt that children in the sixth grade were old enough to understand anthropological concepts. I thought that my chances were greater for finding anthropology in sixth grade texts than in any other primary grade.

I chose to analyze texts from the 1979 adoption because in 1985, when I began my research, school districts were preparing to adopt new social studies texts. It appeared that adoptions would not be complete until after my thesis was finished; if I wanted to get information on what texts school districts had adopted, I would have to delay completion of my thesis, as the figures for the new texts would not be available for some time.

Rationale for the Inclusion of Anthropology in the Social Studies Curriculum

I expected to find anthropology in the textbooks not only because anthropology and the other social sciences had recently been an important part of the curriculum but also because of the definition and goals of social studies.

Social studies is a difficult term to define, as it is a broad subject whose subject matter and purpose is open to differing interpretations. A recent definition given in "In search of a scope and sequence for Social studies: Report of the National Council of Social studies Task Force on Scope and Sequence" (Jarolimek 1984: 251) follows:

Social studies is a basic subject of the $k-12$ curriculum that (1) derives its goals from the nature 
of citizenship in a democratic society that is closely linked to other nations and peoples of the world; (2) draws its content primarily from history, the social sciences, and, in some respects, from the humanities and science; and (3) is taught in ways that reflect an awareness of the personal, social, and cultural experiences and developmental levels of learners.

The definition above "...recognizes the need to deal with social studies content from a global perspective" (Jarolimek 1984:251). A global perspective is an integral part of anthropology, "...the study of humankind, [which] seeks to produce useful generalizations about people and their behavior and to arrive at an unbiased understanding of human diversity" (Haviland 1981:7).

Anthropology not only fits in with the definition of social studies given in the Report of the National Council of Social studies Task Force on scope and sequence, it also meets some of its goals. The first sentence of the goals section of the Report (Jarolimek 1984:251) reads "Social studies programs have a responsibility to prepare young people to identify, understand, and work to solve the problems that face our increasingly diverse nation and interdependent world." By definition, anthropology can help students understand their diverse and interdependent world.

Anthropology is also one of the "important areas of knowledge" the report identifies (Jarolimek 1984:251), 
along with history, geography, government, law, economics, sociology, psychology, humanities, and science.

\section{Review of the Literature}

To find out if anyone already had conducted a study like mine, I reviewed educational and anthropological literature published since 1960. I chose 1960 because most of the post-sputnik government-funded curriculum projects began after that date. I was able to find only a few studies that evaluated textbook content for the inclusion of specific concepts; I cover them briefly in this review. only one study actually looked for anthropological content: in the early 1960s, sady (1976) analyzed five widely used world history textbooks published between 1959 and 1962 . She evaluated the books to determine how they handled the topics of culture, culture patterns and values, culture area, and culture change. Sady found that only culture and culture change were discussed. Authors equated culture change with progress and ignored the processes of change such as innovation, borrowing, and diffusion. sady also found that the books were ethnocentric; for example, the only history the books dealt with was that of Western Europe. The textbook authors virtually ignored the histories of Asia, Africa, South America, and aboriginal North America. 
Unfortunately, sady also discovered many inaccuracies in the anthropological data. The errors usually concerned linguistics, early man, evolution, and race. One book stated that Heidelberg Man is "'...presumed to be the oldest complete skeleton yet unearthed'". Unfortunately, a single jawbone is all the evidence we have ever had of Heidelberg Man. She did find brief explanations of evolution and race; I, however, found occasional references to the concept of race, but never to evolution.

Berlin's study (1972) was similar to mine in that he analyzed seven fifth grade social studies textbooks. The purpose of the analysis was to determine how extensively authors included the concept of cultural relativism. He found that the books were both culturally relativistic and ethnocentric. The cultural relativism was associated largely with American Indians; the ethnocentrism was in discussions of national heroes and of nationalistic beliefs and values. Berlin reported that all the texts had a heavy emphasis on history, geography, and political science, with very little emphasis on the other social sciences.

I found quite a few studies in which the authors were searching for social science generalizations. Israel (1970) conducted an analysis of intermediate social studies textbooks in Mississippi. Her purpose was to determine whether the texts covered selected social science concepts. 
She found that the textbooks included very few social science concepts, other than those in the field of geography. Chew (1966) conducted a similar study of nineteen state-adopted second grade social science texts. She found the amount of social science content varied greatly from book to book, but history received the most attention.

Ratcliffe (1966) analyzed leading eleventh grade American history textbooks and discovered that political and economic terms received far greater coverage than those of the other social sciences. In addition, he found that authors did not attempt to define or explain the meaning of 45 of the 89 terms they used.

The study most similar to mine was in economics. In 1973 the Joint Council on Economic Education conducted a study of social studies textbooks to determine their economic content (Davison 1975). That study became the model for my methodology; I defer its discussion until the methodology section.

When I originally conducted this literature review, I was very disheartened by the dearth of social studies textbook studies. However, a year later, I found many more studies of textbook content (see Andereck and Dixon 1983; Dehuca 1984; the State of Michigan 1984; and Vitz 1985). All of these studies appear to be sound. However, as none of them are directly related to my thesis, I will not discuss them further. 
Significance of the Research

By disclosing exactly what is in the textbooks, this thesis should be of value to anthropologists, educators, persons involved in textbook selection, and the general public. Many anthropologists voice concern that social studies textbooks seem to deal largely with geography and history and ignore anthropology. We need to know whether this perception is accurate.

Educators develop theories about the proper content of social studies and ideally, publishers translate the theories into reality. Do the sixth grade texts really contain what the educators want them to? This thesis helps answer that question. It also tells textbook adoption committees whether the criteria they have set for the texts are being met. 


\section{METHODOLOGY}

\section{Textbook Analysis Methods}

The most basic, and most widespread, method of textbook analysis is reading the text and comparing it to certain criteria. For example, the oregon state Textbook Commission instructs its advisors to read the textbooks in full and then to evaluate them according to specific criteria established by the Textbook Commission. Appendix A is a copy of the criteria the advisors used in evaluating the textbooks that I analyzed. Over the years the criteria have changed, reflecting both social concerns of the times and educational concerns. For instance, the 1960 and 1966 criteria make no mention of the need for recognizing the achievements of minorities. However, the 1972 criteria refer to minority groups twice, and the 1978 criteria mentions the necessity of a multi-ethnic approach several times.

Reading texts and comparing them to specific criteria is actually a simple form of content analysis, best defined as "a research methodology that utilizes a set of procedures to make valid inferences from text" (Weber 1985:9). Although researchers can use content analysis for many purposes, most of the studies on social studies textbooks that 
I found focused on bias against women and various minorities and the issue of readability.

The purpose of this thesis, looking for an unacknowledged thread of anthropology, requires a different approach than content analysis affords. The approach must be as thorough as content analysis. However, it must also recognize that anthropological concepts cannot be conveyed simply by isolated words and phrases. Looking for anthropology is looking for terms and ideas, and is different from looking for bias about certain topics.

In 1973 the Joint Council on Economic Education conducted a study of social studies textbooks to determine their economic content (Davison et al. 1975). The committee evaluating the textbooks began with a framework of economics topics and concepts. Evaluators used the topics and concepts as a reference in determining what economics content of the texts was. I felt that method was also very applicable to a search for anthropological content, and I have based my methodology on it.

I should mention here that this method allowed me to analyze the textbooks strictly for anthropological content. In my analysis of the books I looked only for the anthropology; I did not analyze the books in terms of readability, quality, or interest. Those are educational issues that go beyond the scope of this study. 
Analysis and Data Base

My first task was to develop a framework of topics and concepts basic to anthropology. I selected college level introductory cultural anthropology texts as a guide. The texts I chose were: Kottak, Anthropology: The Exploration of Human Diversity; Keesing, Cultural Anthropology: A Contemporary Perspective; Haviland, Cultural Anthropology; Friedl, Anthropology, The Study of People; and spradley, Anthropology: The Cultural perspective. I chose these particular texts because they were well-known and widelyused introductory texts and because they all had editions published at about the same time as the sixth grade texts that I was analyzing. They were the ideal, the source of basic anthropological knowledge.

I organized my analysis in terms of topics and concepts. "Concept" and "topic" are ambiguous enough terms that they require explanation. The topics are the large categories of information shown in Table I. To derive the topics, I compared chapter titles in the introductory cultural anthropology textbooks. Those chapter titles common to at least three of the five books became the topics.

To derive the concepts used in my thesis, I skimmed the introductory textbooks for the most common ideas and terms that fit under each topic. For example, the topic Marriage and Family includes such concepts as "marriage is a cultural universal" and "monogamy, polygamy, polygyny, 
TABLE I

TOPICS

Nature of Anthropology

Culture change

Nature of Culture

Physical Anthropology

Language and Communication

Growth of Culture

Marriage and Family

Social structure

Kinship and Descent

Psychological Anthropology

Economic systems

Patterns of Subsistence

political systems

Modern Civilizations

Religion and Magic

Cultural Relativity 
polyandry". Appendix $B$ is a full list of the topics and concepts.

Since I derived my topics and concepts from college textbooks, the question arises whether they are suitable and necessary for sixth grade students. I found support for my topics and concepts in Jarolimek (1981:271-272), who included the following concepts in his discussion of anthropological content for the curriculum: language, social structure, religion, arts and crafts, physical and mental traits, and similarities and differences in culture.

The sixth grade textbooks I analyzed were adopted by the oregon State Textbook Commission on November 20, 1979. Titles and publishers of the books are listed in Appendix C. I began my research right before the start of a new social studies adoption cycle, and had difficulty deciding whether to analyze the old textbooks that had been in use for six years or the new ones that school districts were getting ready to adopt. Ultimately I settled on the old texts, since not all school districts would have adopted new texts before my thesis was finished. Since I wanted to know not only what the textbooks were like, but which were in use, I had no choice but to adopt the older ones. The actual analysis of the books was fairly straightforward. For each book I made a packet of worksheets, with one page for each topic, e.g., Nature of Culture. As I 
read a book, I noted each definition or explanation that I felt was anthropological under the appropriate topic. I used the concepts, e.g., "Culture is learned", "polygamy, monogamy", as a guide in deciding under what topic to put each entry.

The hardest part of the analysis was deciding what to do with the wealth of descriptive material. Sixth grade social studies textbooks do not correspond exactly to college texts. Consider the concept of descent. Scott Foresman's Social Studies (Schreiber 1979:23-24) describes how people in Iraq trace their ancestry through males. The text devotes paragraphs of descriptive material to explain this system. The authors are describing a patrilineal system, but they do not use the term patrilineal. In a college text the system would be described, with the term patrilineal an integral part of the description. To catch hidden anthropology such as that, I had to read the textbooks very carefully. Sometimes the descriptive material would be anthropological, and sometimes it would be merely descriptive.

I had intended not only to find out what topics and concepts were covered but also to answer the following questions, the first five of which had been asked in the council on Economics Education study (Davison et al. 1975):

1) What concepts, generalizations, and principles are treated? 
2) Are the concepts important and treated in an analytical manner?

3) Is the order of the anthropological content systematic?

4) Are the anthropological concepts, generalizations, and principles defined, explained, or stated accurately?

5) How interesting and understandable is the treatment of the anthropology for the intended audience?

6) How much of the anthropology could be construed as being sociology?

7) Is the anthropology really anthropology, or is it multicultural education?

8) Is this a very anthropological book?

As I read the books I began to realize that these questions were irrelevant. The quantity of anthropology was so minute, compared to what would be necessary to answer the questions, there really was no way of answering them. I gave up on the questions other than \#l, which became the basis for my analysis.

I not only wanted to know what anthropology was in the books, I wanted to know how anthropological each book was. This was fairly easy to compute. For each book I calculated the number of topics the authors had included in a text as compared to the number of topics I had used in my analysis. I did the same computation for the concepts. I 
have included these quantitative figures in the Results section. 


\section{RESULTS}

The results of my research were many and varied. By analyzing the textbooks, I was able to learn what anthropological topics and concepts were covered, what the quality of the anthropology was, and how much anthropology was in the texts.

\section{Anthropological Topics and Concepts Covered}

Throughout all the books, I found great regularity in what topics and concepts were included and what were almost inevitably absent. Because of this regularity, I am able to present what concepts were covered in table form. Table II lists the topics used to analyze the books, the number of books that included information on the topics, the most frequently mentioned concepts, and the least frequently mentioned topics.

Only one book, Houghton Mifflin: Windows on our World consistently differed from the other books. Complete information on the content of Windows on our world can be found in Appendix $D$, but I would like to point out its highlights. While the other books generally avoided anthropology, it was the basis of Windows on our World. Onethird of the book was devoted to how cultures vary and change, with culture being discussed as the single most 


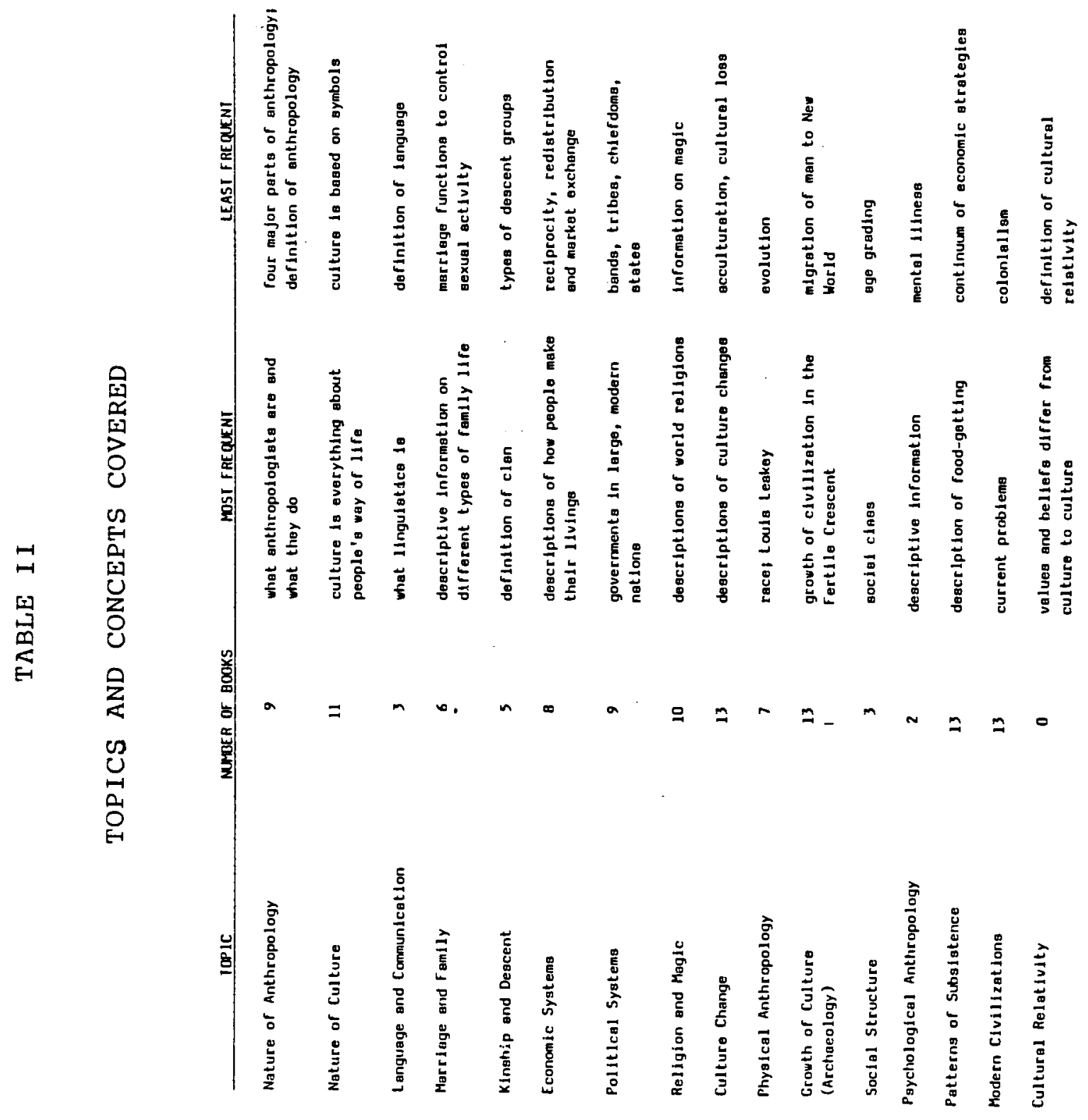


important difference between human beings and animals. The book included an extensive amount of material on language, including such topics as language acquisition, language change, and the genealogical relationships between languages. And, Windows on our World was the only book to contain practically any information on physical anthropology. Discussions centered on the concepts of human beings as primates, taxonomy, genes and skin color, and the validity of the concept of race. I feel that this book is an example of how anthropology can be successfully incorporated into a nationally published social studies textbook.

\section{Quality of the Anthropology}

In all of the books, the bulk of the material was in either narrative or descriptive form. There was very little theory. For instance, scott Foresman: social studies: Grade Six (pg. 29-41) included a whole chapter on religion, giving accounts of the religion of the Cayamura, Iraqi villagers, people in Japan, and people in France. The only theoretical part of the section was a short explanation of what religion is and what shamans are. The rest was pure description. I found the same situation over and over: one small theoretical point, and then pages and pages of descriptive material used to exemplify it.

Not only is theory in short supply, but what is there is sometimes so brief that it is of questionable accuracy. 
I have already noted that the texts define a clan variously as "a huge family", "a group of families sharing a common ancestor", and "groups of large families that form tribes". Anthropologists often consider a clan to be a descent group whose members feel they are related, but do not know exactly how (Haviland 1981). The fact that they do not know how they are related is important; that is what distinguishes a clan from a lineage. In a lineage, the members do know how they are related.

\section{Amount of Anthropology}

Table III displays the percentages of topics included in each book. The numbers look deceptively good: each of the books covered more than 30 of the topics, with some up to 758 and $80 \%$. However, these figures are not representative of the amount of anthropology I found in the books. The reason for this is there are only 16 topics. If a text included even one concept under a certain topic, I considered that topic covered. A book could have one concept from each of the topics, which would mean a 1008 topic coverage, and still not have very much anthropology.

The percentages of concepts covered were far more informative and representative of the amount of anthropology actually in the books. Although there are only 16 topics, there are 129 concepts, a much larger data base. Not surprisingly, the highest score is for Houghton Mifflin: 


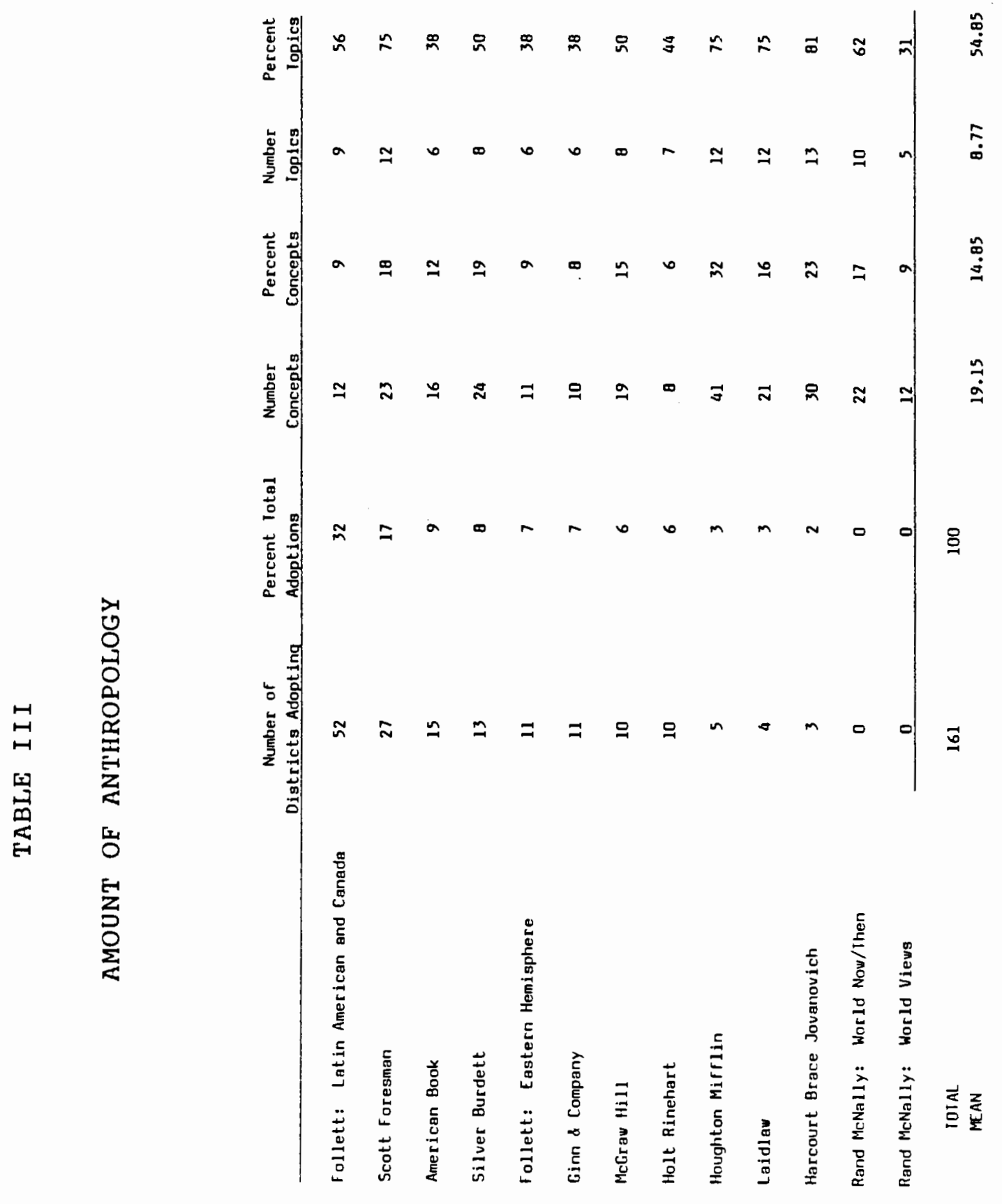


Windows on our World, which consistently included more anthropology than any other book. Lowest score, although others were quite close, was for Holt: Investigating Technology, an almost totally descriptive book. At first glance the textbooks appear anthropological because they deal with so many cultures, but the anthropology is so scarce that it is practically non-existent. Composed largely of historical and geographical information, the textbooks touch only briefly on anthropological topics. The little anthropology I found was scattered throughout the books, in nothing resembling systematic order.

As it has been before, Houghton Mifflin: Windows on Our World is the exception. The anthropology in this text is on more of an equal basis with history and geography, and the organization of the book is similar to an anthropology text. Its four main parts are: (1) What Makes you a Human Being, (2) How and Why are Human Beings Alike and Different, (3) How Does Culture Vary and Change, and (4) Our Urbanized Earth. The authors develop anthropological ideas, rather than randomly scattering them throughout the texts. For instance, in the section on family and marriage, the authors explain nuclear and extended families, monogamy, polyandry, and polygamy. This is not to say that they cover the topic adequately; their discussion of all of these terms takes only two short pages. However that is more information on marriage than any other book presented. 
Conclusion

The question that I pursued in my research was whether there was a thread of anthropology in social studies textbooks. To that question I must answer there is not a thread, but fragments of a thread. The same fragments, also known as topics and concepts, appeared with great regularity in all the books. These fragments are scattered throughout the texts in an unsystematic order, are in large part atheoretical, and vary in accuracy. Some of the books, having quite a few fragments, contain a fair amount of anthropology; others have so few fragments that they are really devoid of anthropology. 


\section{DISCUSSION}

\section{Oregon As A Microcosm}

Although the textbooks that I analyzed were adopted for use in oregon, my guess is that most other states have adopted the same or similar texts. To support this hypothesis, I explored the question whether oregon is representative of other parts of the United states. Oregon is similar to the United States in many respects (U.S. Bureau of the Census: Statistical Abstract of the United States, 1981): the proportion of its population that is urban, the proportion of its population that has graduated from high school, its average expenditures on each pupil in public schools, its per capita income, and the popular vote it cast in the last three presidential elections. However, Oregon differs from the United states in terms of its proportion of white residents. Ninety-four and six-tenths percent of Oregon's residents are white, while the average for the United States is 83.18 (see Table IV).

on the basis of oregon's similarity with the rest of the country, we can expect textbook-related matters in Oregon to be typical of the United states. However, given that we have a less racially diverse population than many other states, there may be less pressure for the inclusion 


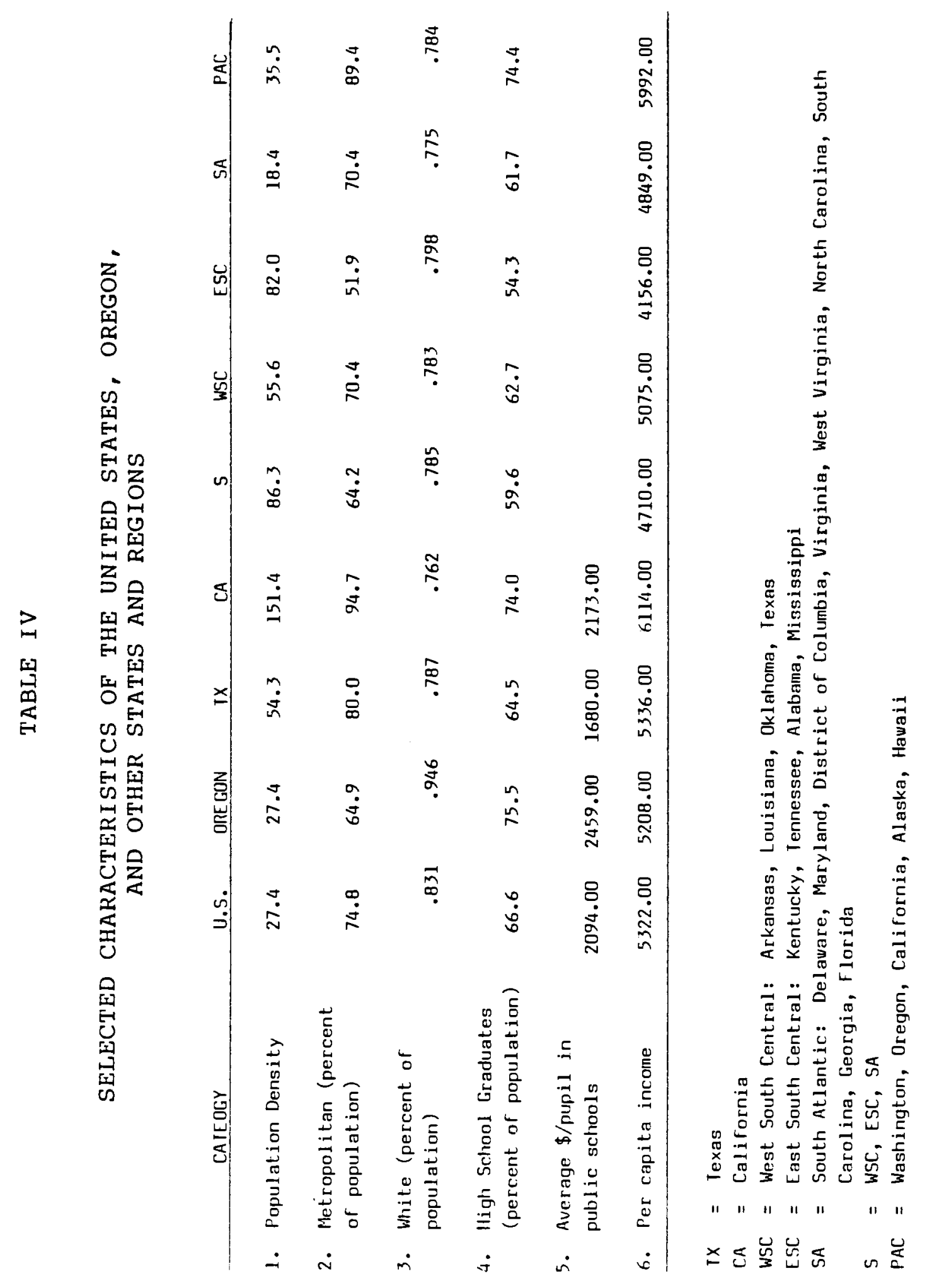


of multicultural information in our texts than in other states.

Textbook Adoption Procedures

The question of whether oregon is a microcosm for the United states is in many ways a moot one, as many factors other than demographics influence the textbooks we select. One of these factors is state textbook adoption procedures. Every state is free to choose textbooks as it pleases, but adoption procedures are basically done in one of two ways: on a statewide level or a local level (Keith 1981). In states that adopt textbooks on a local level, local school boards choose what texts they please rather than having to choose from a state-adopted list of texts. Twenty-eight states adopt in this manner.

When texts are adopted on a statewide level, the usual procedure is for a state committee to choose several series of textbooks for a given subject. Local school boards then choose one or another of the series. Twenty-three states adopt on the statewide level, including oregon. There are, of course, variations in adoption procedures not reflected in the term "statewide". For instance, any school district in oregon that has more than 15,000 students is free to adopt any textbooks it wants, provided the texts meet certain guidelines and criteria that the state Board of Education has established. Any school district with less than 
15,000 can do the same, with state Board of Education approval (Oregon State Board of Education 1986:5).

Many authors (see Keith 1981; Apple 1984; Tulley and Farr 1985) have alleged that large states, such as california and Texas, which adopt textbooks on a statewide basis, have undue influence on the content of the texts. This is referred to as the "Texas and California effect" on the development of textbooks (Tulley and Farr 1985). The idea is that publishers, trying to maximize profits and please as large an audience as possible, write texts that meet the criteria of those large states.

It is not only Texas and California that may have undue influence on the development of textbooks; all 23 states that adopt on a statewide basis may have more bearing on the development of texts than those that adopt by local school district. Although many states use statewide adoption, they are concentrated in the South; Alabama, Arkansas, Florida, Kentucky, Louisiana, Mississippi, North Carolina, Oklahoma, South Carolina, Tennessee, Texas, Virginia, and West Virginia all adopt on a statewide basis. Publishers argue (Tulley and Farr 1985) there are no major differences in curricula between the large statewide adoption states and local school districts in open states. In addition, Keith (1981) surmises that the influence of those large states is greater on non-content areas of the texts than on content areas. 
If we acknowledge that Texas, California, and most of the southern states have at least some influence on texts before they are even offered to oregon for adoption, the question becomes not whether oregon is a microcosm for the United States, but whether Texas, California, and the south are microcosms for the United states and further, how similar they are to oregon. I do not want to prolong the point any further. Table IV summarizes the similarities and differences among the areas.

\section{The Exclusion of Anthropology}

I feel that the exclusion of anthropology from social studies textbooks is occurring at several different levels in the textbook production and adoption process. In concluding this thesis I would like to discuss where and why the exclusion may be occurring.

As anthropology would be an ideal component of the social studies (see Dynneson 1975), its exclusion is quizzical. Given the strong tradition of history as the prime component of social studies (Dynneson 1975), the incorporation of anthropology into the field would be an innovation. Anthropologists are well aware that the acceptance or rejection of innovation is a complex matter; Homer Barnett based a whole book (1953) on the topic.

In "The Gatekeepers: Monitors of Textbook Innovation", Thompson (1984) delineates the places of possible 
resistance to innovation in the textbook production and adoption process. Her paper is in part based on cronbach's (1955) model of gatekeepers in the production and use of textbooks. Cronbach sees (Figure 1) the gatekeeper as a selector of messages in the line of communication involving textbooks; the gatekeeper allows some messages to pass on to the next gate and excludes others. There are numerous gatekeepers involved in textbooks: authors, publishers, adoption committees, to name a few. Cronbach's model is linear, and in terms of the very complex systems models now in common usage, perhaps a naive one. However, his basic concept is sound.

In her 1984 paper, "The Gatekeepers: Monitors of Textbook Innovation," Thompson builds on Cronbach's model, creating a systems view of the gatekeeping process. She describes the system basically as one in which publishers receive input from the society and then create textbooks based on that input. Literally everyone in the system can be a gatekeeper, although each participant's gatekeeping actions differ.

Thompson maintains that innovation in textbooks can be limited or furthered at each gate. The primary gatekeeper is the publisher, who makes business decisions about what enters and what is barred from the knowledge distribution system. The term knowledge distribution system refers to the system which includes the writing, editing, designing, 


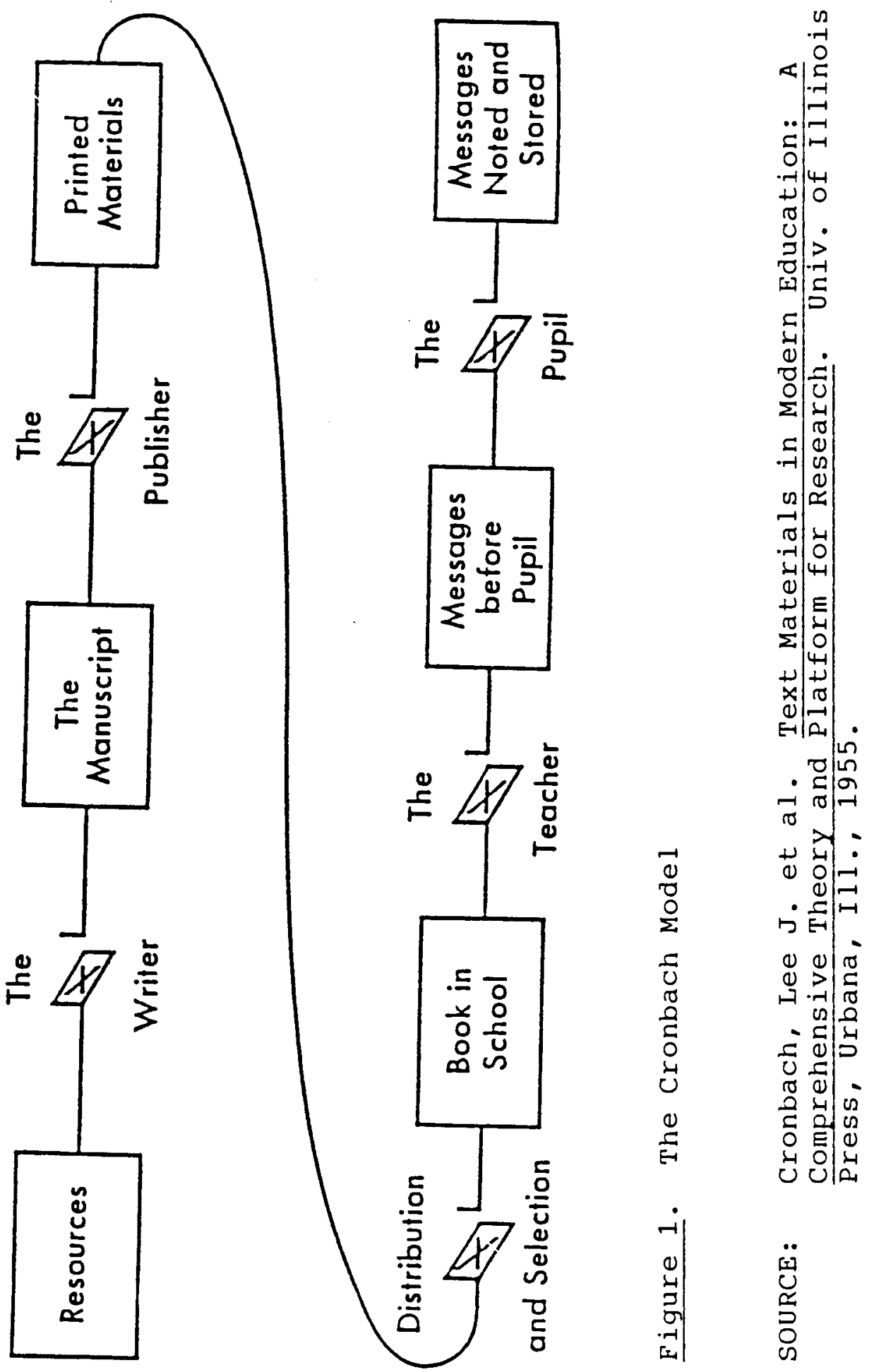


packaging, and publishing of textbooks (Thompson 1982) what most of us think of as the publishing industry. According to Keith (1981), publishers base their decisions to undertake publication of a textbook on economic rather than educational considerations. They make decisions that minimize financial risk (Thompson 1984).

Publishing houses, like all other capitalistic businesses, obviously have to show a profit or they will go out of business. Broudy (1975) argues that the cost of publishing limits the publication of innovative programs. The actual production of a textbook is a very long process, from two to five years, and may cost several million dollars. When a publisher considers publishing a new text, he wants to be sure that it will sell in the largest number of markets. To insure the saleability of a book, the publisher does market studies of the buying trends of the major states (Keith 1981). It is here that the states that adopt on a statewide basis are influential; publishers closely consider their needs, wants, and values when planning the text. How much influence the large states have on content is arguable; Keith (1981) suggests that the influence is more over the quality of production standards than content.

Statements from publishers in explanation or defense of their decisions are rare; Thompson refers to their decisions as "black box" decisions, not open to public scrutiny 
(1984:9). However, James R. Squire, president of Ginn and Company at the time he made the statement, reveals $(1981: 28)$ :

But given the high risk investment decisions documented .... few publishers will or can consciously risk exclusion from adoption procedures by ignoring widespread customer preferences, however they might wish to do so. Every major educational publisher can discuss the distinguished failures in his publishing list during the past decade or two. For the most part, these have been programs of quality which introduced innovations different from those most schools were ready to accept.

It appears that the cost of publishing constrains a "publisher's capabilities for initiating innovative programs" (Broudy 1975:133) and that publishers often must close the gate on innovations when first deciding what to publish. In other words, anthropology, as an innovation, may never make it past the publisher. If, however, anthropology or any other innovation makes it past the publisher, there are other gatekeepers ahead.

The secondary gatekeepers are the in-house personnel of the publishing houses. This group includes editors, writers, authors, consultants, and sales staff. Of primary importance is the editor, who functions as the assembler of the textbook. If the editor is well-informed, imaginative, and creative, he may push for innovative approaches and may well gather like-minded people to create the text (Thompson $1984)$. 
The tertiary gatekeepers include the government, families, school administrators and teachers, and theorists and researchers in education. Any of these groups can do their share in limiting innovation. Educators may conduct research that results in their advocating the status quo in social studies. Teachers may teach strictly by the book, which we already know is probably not innovative. Adoption committees may be educationally conservative, thereby rejecting new approaches or may set criteria that force publishers to publish non-innovative texts.

Anthropology, as an innovation, can be excluded from textbooks at any or all of the three gatekeeping levels in the system. Because the gates are in a system, change anywhere will have ramifications throughout the system.

\section{Accomplishing Change}

On the basis of my research, I cannot help but conclude that the particular group of social studies textbooks I studied are almost devoid of anthropology. I see anthropology being excluded in various parts of the textbook process. The inclusion of anthropology in the textbooks would constitute an innovation.

If anthropologists, or any other interested parties, wish to promote this innovation, then they must influence the gatekeepers who are responsible for the exclusion. They must increase the gatekeepers' understanding of and 
receptivity to anthropology. The number of places in which anthropologists could promote anthropology as an innovation is obviously extensive, and a bit overwhelming. Before they characterize the system as unapproachable, they should remember that change in any part will reverberate throughout the system.

Change is possible. A view of anthropology as a perfectly normal part of social studies texts can replace the view of anthropology as innovation. Barnett (1953) stresses the importance of advocates in the acceptance of an innovation; anthropologists must become those advocates. When anthropology departments receive requests for speakers at such places as public schools, they can take the time to honor those requests. The American Anthropological Association can follow the example of the American Psychological Association's efforts (Selig 1981) in promoting the teaching of psychology at the secondary level.

Anthropologists can become involved in the textbook process in a multitude of ways, including writing texts and being on adoption committees. Anthropologists can talk to publishers about anthropology, can help states with textbook criteria and reviews. If we don't start educating children early about anthropology, we may never get to educate them at all. It is time for anthropologists to come out of their offices and into the real world. 
REFERENCES CITED

Allen, Jack

1979 American Book Social studies: Cultures. New York: American Book.

Andereck, Mary E. and C.V. Dixon

1983 Latin America in World Geography Textbooks for the Secondary school. Paper presented at the annual meeting, National Council for Geographic Education. ED 240013 .

Anderson, Lee $\mathrm{F}$.

1976 Windows on our World: The Way People Live. Boston: Houghton Mifflin.

Anderson, Edna A.

1979 Silver Burdett Social studies: People in the Eastern Hemisphere. Morristown: Silver Burdett.

Anthropology Curriculum Project

1965 The Concept of Culture: Comparative cultures: Grade Four. Athens: University of Georgia.

Anthropology Curriculum study Project

1971 Patterns in Human History. New York: The Macmillan Co.

Apple, Michael $W$.

1984 The Political Economy of Text Publishing. Educational Theory 34: 307-319.

Barnett, Homer

1953 Innovation: The Basis of Cultural Change. New York: McGraw Hill.

Barr, Richard D., J.L. Barth, and S.S. Shermis

1977 Defining the Social studies. Arlington: National Council for the social studies.

Bednarz, Robert I.

1980 Our widening World: The World Now and Then. Chicago: Rand McNally.

1980 Our widening World: World Views. Chicago: Rand McNally. 
Berlin, William 0 .

1972 An Analysis of Selected Elementary School Textbooks to Determine the Extent of Inclusion of the Anthropological Concept of Cultural Relativity. Terre Haute: unpublished Ph.D. dissertation, Indiana state University.

Brandwein, Paul F.

1975 The Social Sciences: Concepts and Values: Brown Level. New York: Harcourt Brace Jovanovich.

Broudy, Eric

1975 The Trouble with Textbooks. Teachers College Record $7: 130-134$.

Bruner, Jerome

1960 The Process of Education. Cambridge: Harvard University Press.

Cherryholmes, Cleo H.

1979 McGraw-Hill Social studies: Investigating Societies. New York: McGraw-Hill.

Chew, victoria

1966 Social Sciences Generalizations in selected

Second Grade Textbooks. Unpub. Ph.D. dissertation, University of California, santa Barbara.

Cronbach, Lee J. et al.

1955 Text Materials in Modern Education: A Comprehensive Theory and Platform for Research. Urbana: University of Illinois Press.

Davison, Donald G., L.G. Sgontz, and R. Shepardson

1975 Economics in Social Studies Textbooks: An Evaluation of the Economics and the Teaching strategies in Social studies Textbooks, Elementary Grades (1-6). Iowa City: Bureau of Business and Economic Research. College of Business Administration, University of Iowa.

Dehuca, Richard

1984 In Search of the "Real" California: History in the 4 th Grade Textbook. Paper presented at the CLIO Conference. ED 253478

Durbin, Kathie

1986 'Get Oregonized' Editor Gets Mixed Signals. oregonian $136(44,721)$ : B8. April 16 . 
Dynneson, Thomas

1975 Pre-Collegiate Anthropology: Trends and Materials. Athens: University of Georgia. Anthropology Curriculum Project.

Education Development Center

1970 Man: A Course of Study. Washington, D.C.: Curriculum Development Associates, Inc.

EPIE

1977 Report on a National Study of the Nature and Quality of Instructional Materials Most Used by Teachers and Learners. EPIE Report No. 76. New York: Educational Products Information Exchange Institute.

Fiedler, William R.

1976 Holt Databank System: Inquiring About Technology. New York: Holt Rinehart Winston.

Fitzgerald, Frances

1979 America Revised: History Schoolbooks in the 20th Century. Boston: Little, Brown and Company.

Friedl, John.

1977 Anthropology: The Study of People. New York: Harper and Row.

Gross, Henry A.

1977 Exploring Our World: Eastern Hemisphere. Chicago: Follett.

1977 Exploring our World: Latin America and Canada. Follett.

Haviland, W.A.

1981 Cultural Anthropology. New York: Holt, Rinehart, Winston.

Higgins, Patricia J, and Ruth O. Selig

1980 Teaching Anthropology to students and Teachers: Reaching a Wider Audience. Athens: University of Georgia. Anthropology curriculum Project.

Israel, Jewel M.

1970 A Study of the Extent to which selected social Science Concepts are Included in Intermediate Grade Social Studies Textbooks. Unpub. Ph.D. dissertation, Univ. of Southern Mississippi 
Jarolimek, John

1981 The Social studies: An Overview in $\mathrm{H}$. Mehlinger, ed. The Social studies. Chicago: National Society for the study of Education.

1984 In Search of a scope and sequence for Social Studies: Report of the National Council of Social Studies Task Force on Scope and sequence. Social Education 48(4):250-258.

Keith, sherry

1981 Politics of Textbook selection. Palo Alto: Institute for Research on Educational Finance and Governance, Stanford University.

Keesing, Roger $M$.

1976 Cultural Anthropology: A Contemporary Perspective. New York: Holt, Rinehart, and Winston.

King, Fredrick M., H.C. Rudman, LoDoris R. Leavell

1979 Understanding the Social Sciences: Understanding the World. River Forest: Laidlaw.

Kottak, Conrad R.

1982 Anthropology, The Exploration of Human Diversity. New York: Random House.

Nelkin, Dorothy

1977 Science Textbook Controversies and the Politics of Equal Time. Cambridge: The MIT Press.

Oregon state Board of Education

1986 Circular of Information re: The Adoption of Textbooks in Oregon. Salem: Oregon state Board of Education.

Oregon State Textbook Commission

1978 Circular no. 2, List of State-Adopted Basal Textbooks for Home Economics, Music, \& Social

Studies. Salem: Oregon State Textbook Commission.

Ratcliffe, Robert $\mathrm{H}$.

1966 A Critical Analysis of the Treatments Given Representative social Science Ideas in Leading lith Grade American History Textbooks. Unpub. Ph.D. dissertation, Northwestern Univ. 
Sady, Rachel R.

1976 Anthropology and world History Texts. In S.I. Roberts and S.K. Akinsanya, ed., Patter $\frac{1}{n s}$ and Cultural Configurations: The Anthropology of Education. New York: David McKay Company.

Schreiber, Richard T.

1979 Scott, Foresman Social studies: Grade Six. Glenview: Scott, Foresman.

Selig, Ruth 0 .

1981 Anthropology in the Classroom: Perspectives and Prospects. In Teaching Anthropology to students and Teachers: Reaching a wider Audience. P.A. Higgins and R.O. Selig, ed. Athens: University of Georgia. Anthropology Curriculum Project.

Spradley, James P.

1975 Anthropology: The cultural perspective. New York: John Wiley and Sons.

Squire, James R.

1981 Publishers, Social Pressures, and Textbooks. In The Textbook in American Society. John Y. Cole and T.G. Sticht. Washington, D.C.: Information office, Library of congress.

State of Michigan

1984 Michigan Social studies Textbook study; A study of Selected Eighth Grade United States History Textbooks. ED 249142

Thompson, Patricia J.

1982 The Textbook in the Ecology of Education. Paper presented at American Educational Research Association Annual Meeting. ED 219317.

1984 The Gatekeepers: Monitors of Textbook Innovation. Paper presented at American Educational Research Association Annual Meeting. ED 246402 .

Tiegs, Ernest W. and F. Adams

1979 Our Land and Heritage: Our world. Boston: Ginn.

Tulley, Michael A. and Roger Farr

1985 The Purpose of State-Level Textbook Adoption: What Does the Legislation Reveal? Journal of Research and Development in Education 18:1-6. 
U.S. Bureau of the Census

1981 Statistical Abstract of the United States: 102nd edition. Washington D.C.

Vitz, Paul C.

1985 Religion and Traditional Values in Public School Textbooks: An Empirical Study. Washington D.C.: National Institute of of Education.

Weber, Robert $P$.

1985 Basic Content Analysis. Beverly Hills: Sage Publications.

Wiley, Karen

1977 The Status of Pre-college Science, Mathematics, and Social Science Education: 1955-1975, Vol. 3 Washington, D.C.: Government Printing office. 


\section{APPENDIX A}

STATE TEXTBOOK COMMISSION

942 Lancaster Drive, NE

Salem, Oregon 97310

378-3610

19787

Criteria for the Selection and Adoption of

SOCIAL STUDIES TEXTBOOKS*

(OAR 581-11-109, established by the State Board of Education, 1-5-78)

All specific criteria will be considered when evaluators examine and rate textbooks. Textbooks shall be rated according to their degree of compliance with the criteria presented herein:

\section{SOCIAL STUDIES CATEGORIES:}

Grades K-3 (Content may be extended into Grade 4)

LIVING IN HOMES, SCHOOLS, NEIGHBORHOODS, AND COMMUNITIES--with emphas is on personal development. (Materials may provide comparative studies around the world; be flexible enough to be used at whatever grade level meets the need of the individual student or class and follows sound educational practice; and be cross-discipline courses.)

Grades 4-6 (Content may be begun in Grade 3)

LIVING IN REGIONS AND NATION(S) (COMPARATIVE CULTURES--PAST AND PRESENT)

Grades 4-6: Oregon and/or the Pacific Northwest

$\star \star$ Grades 7-9:

Geography: Cultural, Physical, Political

United States History and Government--National Development to the Present History and Geography of Oregon and/or the Pacific Northwest Local and State Government

Citizenship

$\star *$ Grades $9-12$

United States History - (a) National Development to the Present

Citizenship

- (b) Beginning of the 20th Century to the Present

United States Government (emphasis on political institutions and behavior) World Cultures

World History

Contemporary Issues

Economics

Sociology

Psychology

"In these criteria, wherever the word "textbook" or "text" is used, it may be construed to mean "textbooks and/or instructional materials."

* NOTE: Oregon Law (ORS 336.057) requires courses in the Constitution of the United States and in the history of the United States be given in all public and private schools and requires that the courses "shall begin not later than the opening of the eighth grade and shall continue in grades 9 through $12 . "$ 


\section{SPECIFIC CRITERIA FOR SOCIAL STUDIES}

1. ILLUSTRATIONS within texts should:

A. Effectively complement the narrative; e.g., to dramatize an event or highlight major issues.

B. Reflect a balanced selection of charts, cartoons, maps, photographs, and reproductions of art appropriate to the historical setting.

c. Portray a society's various groups; e.g., ethnic, cultural, etc.

II. OBJECTIYES within texts should:

A. Be stated clearly, appropriate for the grade level, and written in terms of behavioral outcomes.

B. Balance the cognitive with the affective.

C. Be kept to a total manageable number.

D. Lead students toward developing and clarifying their views of commonly held societai values (e.g., justice, truth, honesty).

III. PRESENTATION OF CONTENT within texts should:

A. Present a variety of learner strategies; e.g., problem-solving, inquiry, decision-making skills, discovery, interpretation.

B. Aid students in developing thinking skills such as comprehension, analysis, synthesis, application and evaluation.

c. Encourage a variety of learner activities such as observation, data acquisition, independent study, discussion and committee work and writing.

D. Include a variety of approaches to complement different learning styles and abilities.

E. Present ethical issues to help students rationaliy evaluate their own positions on issues, etc.

F. Be weil organized in a logical sequence.

G. Reflect a multidisciplinary approach.

H. Be appropriate to the student's age and level of understanding.

I. Exhibit a multiethnic, $\rightarrow$ mul ticultural apprach in depicting minörfty groups - Fincluding Native Americans, Black Americans, Asian Americans, Mexican Ameri-

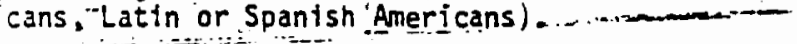


J. Adequately represent the values, mores, and cultural contributions of ethric and racial groups.

K. Portray persons of different ethnic groups in positive social relationships.

L. Encourage students to understand the interrelationships of other cultures, economic conditions, political developments, geographic factors, and social; phenomena both within and between cultures.

M. Explore career possibilities within the social sciences.

N. Encourage the use of the community as a resource.

0 . Organize data according to concepts and generalizations $)$

P. Deal with facts as established points of view rather than absolutes.?

Q. Use recent, accurate social science data.

R. Interpret historical information based upon authentic historical data.

IV. THE STYLE AND TONE of the text should reflect a recognition and appreciation of the human dignity as well as the uniqueness of various racial, ethnic, religious or geographic groups. The materials should:

A. Be free of value-laden, ethnocentric, or charged words and terminology; e.g. , : uncivilized,_Red China, dark continent._is._._.

B. Be free of judgmental, patronizing, or condescending implications.

C. Present the way of life of a given group of people within the context of their cultural values systems.

D. Be written at a level of difficulty and abstraction appropriate to the students using them.

E. Present the roles of various religious, political, and socio-economic groups accurately and fairly.

V. LEARNER APPROPRIATENESS: Content and methodology within texts should be appropriate to students grade and ability, and should:

A. Clearly explain new vocabulary terms and concepts within context of the reading.

B. Use chapter and marginal headings to enhance learner understanding of trie content.

C. Include chapter sumaries to reinforce main concepts and themes. 
-4-

D. Highlight the perspectives provided by history and the social science disciplines.

E. Suggest a range of learning activities to meet students backgrounds, learning styles and abilities, including: visual and auditory learning activities, simulations which reinforce concepts, activities relating concepts to realistic situations, activities enabling students to draw upon their personal experiences and background.

F. Emphasize the range of skills found in the cognitive and affective domains.

G. Encourage the development of insights and perspectives which history and the social science disciplines provide. 

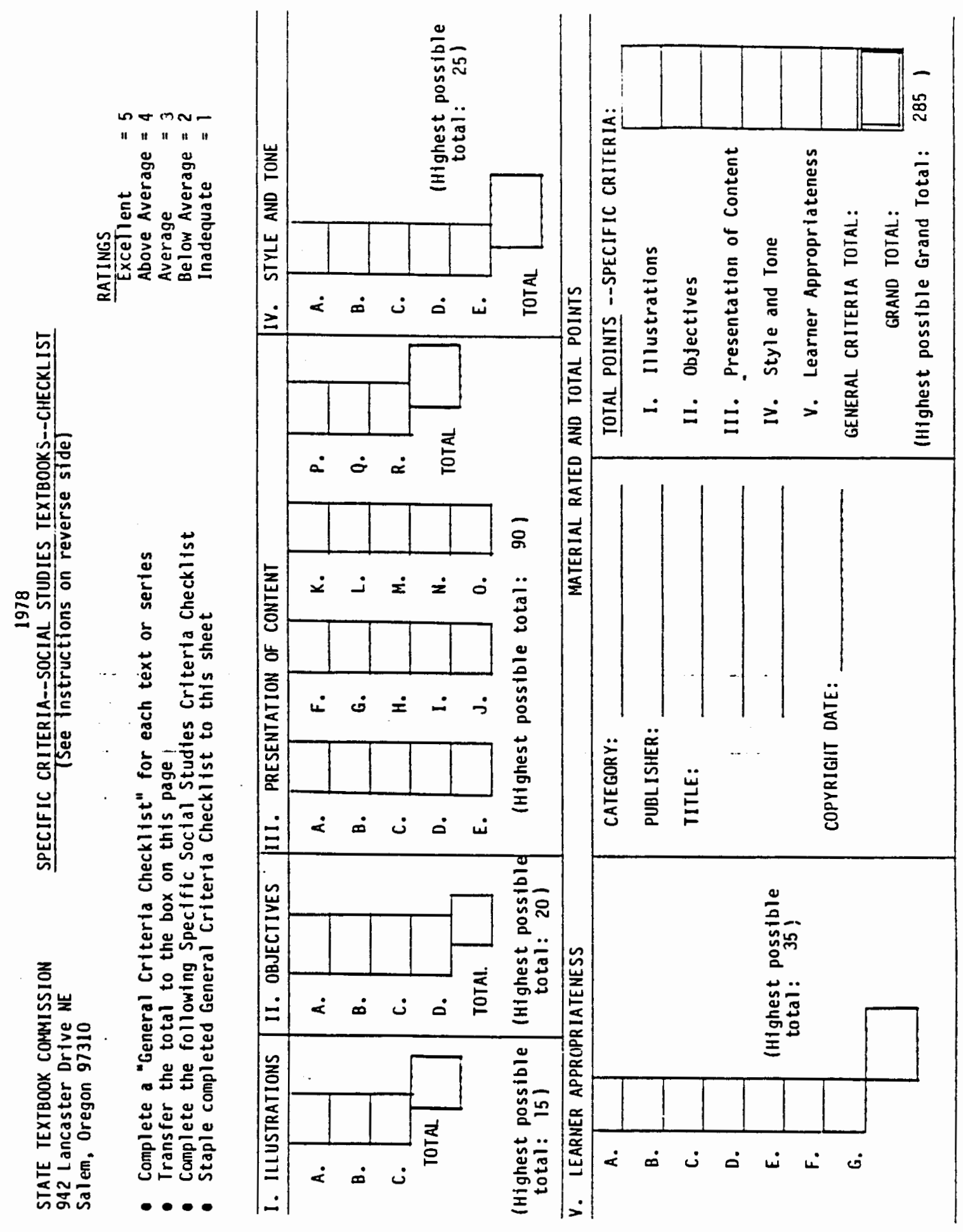

$-5-$ 
STATE TEXTBOOK COMMISSION

942 Lancaster Drive, NE

Salem, Oregon 97310

378-3610
$-6-$

1978

INSTRUCTIONS FOR USING THE SOCIAL STUDIES CRITERIA CHECXLIST

Please note that two checklists are to be completed for each textbook or series:

(1) A checklist for "General Criteria for A11 Textbooks"

(2) A checklist for"Specific Criteria for Social Studies Textbooks"

The total points on the General Criteria Checklist are to be transferred to the Specific Criteria Checklist where a box is provided for this; thus, the General Criteria Checklist points will be added into the Grand Total score given the text.

PROCEDURE:

1. Evaluate a text or series

2. Determine the degree to which the text or series meets the Eriteria itens on the General Criteria Checklist. (The General criteria and checklist are combined on one sheet.)

3. Assign a point value to each section of the General Criteria according to the instructions.

4. Total the points for each section of the General Criteria, record in the appropriate boxes on the Ceneral checklist, and transfer the total to the appropriate box on the Social Studies Specific Criteria Checklist.

5. Determine the degree to which the text or series meets each item of the Specific Criteria.

6. Assign a point value to each item of the Specific Criteria using the rating scale below.

NOTE: If a criteria point is not applicable to the particular text or subject, PLEASE MARK IT "N/A" (not applicable) AND GIVE IT NO NUMERICAL SCORE.

7. Total the points for each section of the Specific Criteria.

Record the totals in the appropriate boxes on the checklist.

Add in the total points from the General Criteria Checklist, and record the final total in the Grand Total box.

8. Staple the General Criteria Checklist to the Specific Criteria Checklist.

\begin{tabular}{ll}
\hline RATING SCALE FOR SPECIFIC CRITERIA: & Excellent $=5$ \\
Above Average $=4$ \\
Average $=3$ \\
Below Average $=2$ \\
Inadequare $=1$
\end{tabular}

IMPORTANT: Please double-check all additions on numbers recorded in all "total" boxes. Accuracy in totaling points is extremely important. 
$-7-$

STATEMAENT REGARDING EVALUATED TEITSOOK

(Optional)

Evaluator: If, after completing the checklists for a text or series, you would like to make coments regarding it, please use the form below and attach it to the completed checki ists.

1. Major strengths of the text or series:

2. Major weaknesses of the text or series:

3. General coments re the text or series:

Evaluator or Committee:

Publisher:

Category:

Title: 


\section{APPENDIX B}

TOPICS AND CONCEPTS USED IN TEXTBOOK ANALYSIS

1. The Nature of Anthropology

a. the study of man

b. four major parts

c. fieldwork

d. cultural anthropology is comparative

e. what an anthropologist is

2. The Nature of culture

a. culture is shared, learned, based on symbols

b. subcultures and pluralistic societies

c. enculturation allows for culture to continue

d. there are certain universal parts of culture

e. is man's way of adapting to environment

f. what people know about how to behave and how to survive in society

9. have historically been many different views about what culture is

h. cultures change

i. what people share, e.g., religious values, customs 
3. Language and Communication

a. language is system of sounds, when put with rules, results in meanings intelligible to all speakers

b. language is a system, in symbols, for the communication of information

c. definition of linguistics

d. phonetics, phonology, phonemes, morphemes, grammar

e. languages change

f. genealogical relationships between languages

g. origins of language - primate studies

h. language acquisition

i. communication by non-verbal means

4. Marriage and Family

a. marriage is a cultural universal

b. marriage functions to control sexual activity

c. family functions as unit of socialization, for passage of property

d. marriage establishes relationships between groups

e. size and form of family varies, e.g. nuclear, extended

f. monogamy, polygamy, etc.

g. types of residence

h. exogamy and endogamy

i. definition of marriage 
j. incest

k. marriage forms vary

1. family provides help and companionship

m. family, in some form, is universal

n. bridewealth, brideprice

5. Kinship and Descent

a. kinship groups help people deal with problems too large for small family

b. descent group: members trace membership back to ancestor

c. matrilineal, patrilineal, bilateral kinship

d. lineage, clan, phratry, moiety

e. kinship terminologies, e.g. Hawaiian

f. kinship diagram

6. Economic systems

a. economic system is one in which goods are produced, distributed, and consumed

b. patterns of labor in every society, e.g., division of labor

c. yearly economic cycle of production

d. distribution of goods by reciprocity, redistribution, market exchange

e. wants and needs

f. property

g. money

h. technology 
7. Political systems

a. political organization is the means through which a society maintains social order

b. four kinds political systems: bands, tribes, chiefdoms, states

c. sanctions: externalized social controls

d. laws

e. wars

f. government is an administrative system having specialized personnel

g. governments form because some jobs are too big to do

8. Religion and Magic

a. definition of religion

b. religion consists of rituals through which people try to manipulate supernatural beings and powers to their advantage

c. there are certain people who deal especially in this, e.g., shamans and priests

d. religions reduce anxiety by explaining the unknown

e. religions maintain social solidarity

f. provide notions of right and wrong

g. ritual is religion in action

h. ancestral spirits

i. animism - nature is animated by spirits 
j. rites of passage

k. magic

1. witcheraft

m. revitalization movements

n. myths and sacred tales

o. millenarian movements

p. totemism

9. Culture Change

a. all cultures change, for a variety of reasons

b. environment may require an adaptive change

c. invention

d. diffusion

e. cultural loss

f. acculturation

g. modernization

h. human societies are subject to laws of evolution

i. sometimes governments plan change

10. Physical Anthropology

a. humans are most closely related to other primates

b. by studying primates we can understand our development

c. various fossil men

d. man evolved from apes

e. examples of primate social behavior

f. communication in apes

g. genetics 
h. races

i. tools and hominids

11. The Growth of Culture (Archaeology)

a. what archaeologists are

b. what archaeology studies

c. cave art

d. origin of food production

e. rise of cities and states

f. migration to America

12. Social structure (Class, Caste, Age Groups, etc.)

a. age grading

b. common interest associations

c. social stratification

d. egalitarian or stratified societies

e. caste

f. social class - equal prestige

g. status - certain rights and duties

h. role - expected behavior

i. division of labor

13. Psychological Anthropology

a. enculturation

b. modal personality

c. abnormal personality is relative concept

d. world view - way a culture perceives its environment 
e. world view and values manifest themselves in the individual as personality

f. different ways of raising children

g. adjusting to life cycles

14. Patterns of Subsistence

a. man adapts to his environment to survive

b. hunting/gathering, horticulture, agriculture, pastoralism

c. culture area and culture core

15. Modern Civilizations, Cities, Peasants

a. technology and man continue to change

b. men will be working to create decent environments

c. development and underdevelopment as adaptation problem

d. colonialism

e. cities

f. peasants

16. Cultural Relativity

a. a culture must be evaluated according to its own standards

b. world views differ

c. ethnocentrism

d. every culture is as worthy of respect as the rest e. values vary by culture

f. values provide the basis for behavior and goals, which differ culture to culture 
APPENDIX C

PUBLISHERS AND TEXTBOOK TITLES

1. American Book: Book $F$, Cultures

2. Follett: Eastern Hemisphere

3. Follett: Latin America and Canada

4. Ginn and Company: Our World

5. Harcourt Brace Jovanovich: The Social Sciences: Concepts and Values: Brown Level

6. Holt: Inquiring About Technology

7. Houghton Mifflin: Windows on Our World

8. Laidlaw: Understanding the World

9. MCGraw Hill: Investigating Societies

10. Rand McNally: The World Now and Then

11. Rand McNally: World Views

12. Scott Foresman: Social Studies: Grade Six

13. Silver Burdett: People in the Eastern Hemisphere 
APPENDIX D

TOPICS AND CONCEPTS COVERED IN HOUGHTON MIFELIN;

WINDOWS ON OUR WORLD: THE WAY PEOPLE LIVE

TOPIC

Nature of

Anthropology

Nature of

culture

Language and

Communication
CONCEPTS COVERED

no definition of or information about anthropology; anthropologists are scientists who study human beings

One-third of book devoted to how cultures vary and change; culture is the single most important difference between human beings and animals; language, technology, institutions, and beliefs are its four parts; there are 70 or more cultural universals which vary from society to society.

definition of language; info on language acquisition, grammar, language change, genealogical relationships between languages 
Marriage and

Family

Kinship and

Descent

Economic systems

Political systems

Religion and

Magic

Physical

Anthropology

Growth of

Culture Social structure no information

Psychological

Anthropology religions definition of nuclear and extended families, monogamy, polygamy, polyandry; family may have been the first institution; form of the family varies.

no information given

information about technology

formation of ancient governments

information on beliefs, rites of passage, values, and the five major

human beings are primates; physical differences between humans and other animals; taxonomy; genes and skin color; validity of concept of race archaeologists and prehistory

section on psychological needs; compared needs of a boy in Indian and one in Mississippi 
Subsistence

Modern

Civilization

Cultural

Relativity information spread throughout book problems of urbanization in Turkey, Laos, Chicago, Yugoslavia, and Zambia; differences in friendship patterns in small city and suburb

we are all likely to think our own way of doing something is the only "right" way 